\title{
LETTER
}

\section{Omeprazole-associated rhabdomyolysis}

\author{
Kumiko Tanaka', Taka-Aki Nakada ${ }^{1 *}$, Ryuzo Abe ${ }^{1}$, Sakae Itoga ${ }^{2}$, Fumio Nomura ${ }^{2}$ and Shigeto Oda ${ }^{1}$
}

Proton pump inhibitors (PPIs) are commonly used in ICUs. Here, we report a severe case of rhabdomyolysis associated with omeprazole. A 20-year-old man, who previously had been healthy, visited a hospital with epigastric pain. An upper gastrointestinal endoscopy revealed a duodenal ulcer in an active stage. He was admitted to the hospital and received intravenous omeprazole $(20 \mathrm{mg})$ twice a day. On day 14 of admission, he developed muscular pain, predominantly in the lower extremities, and had elevated serum creatinine phosphokinase (CPK) $(28,314 \mathrm{IU} / \mathrm{L}$; normal is less than $25 \mathrm{IU} / \mathrm{L})$ (Figure 1). The patient was transferred to the hospital's ICU on day 16 , since the serum CPK $(112,240 \mathrm{IU} / \mathrm{L})$ and myoglobin $(25,082 \mathrm{ng} / \mathrm{mL}$; normal is less than $154 \mathrm{ng} / \mathrm{mL}$ ) levels were extremely high. After potential causes of elevated CPK were considered, omeprazoleassociated rhabdomyolysis seemed the most probable diagnosis. We discontinued intravenous omeprazole administration and started aggressive fluid repletion, continuous renal replacement therapy, and urine alkalization. The CPK and myoglobin levels successively decreased and reached within the normal range on day 31 . The patient recovered completely and was discharged on day 38 .

No allergic symptom was detected in this case. The results of a drug-induced lymphocyte stimulation test for omeprazole were negative. Altered pharmacokinetics of omeprazole has been reported in patients with genetic variations in CYP2C19, which encodes a principal enzyme to metabolize omeprazole [1]; therefore, we performed DNA sequencing of the entire coding regions in CYP2C19. The analysis revealed no serious loss-of-function variations in the gene (intermediate metabolizer genotype) [1]. The plasma omeprazole level on day 15 was within normal range $(380 \mathrm{ng} / \mathrm{mL}$; normal is less than $400 \mathrm{ng} / \mathrm{mL}$ ) [1]. Thus, the metabolism and plasma levels of omeprazole were not likely to be associated with rhabdomyolysis.

\footnotetext{
* Correspondence: taka.nakada@nifty.com

${ }^{1}$ Department of Emergency and Critical Care Medicine, Chiba University Graduate School of Medicine, 1-8-1 Inohana, Chuo, Chiba 260-8677, Japan Full list of author information is available at the end of the article
}

PPI-associated rhabdomyolysis is generally rare. This case had extremely high $\mathrm{CPK} /$ myoglobin levels compared with those reported earlier $[2,3]$. The mechanism of PPI-associated rhabdomyolysis has not yet been fully elucidated. Omeprazole is known to specifically bind to $\mathrm{H}^{+} \mathrm{K}^{+}$-ATPase at the gastric parietal cells. $\mathrm{H}^{+} \mathrm{K}^{+}$-ATPase is present in other tissues, including vascular smooth muscle cells [4]. Blocking $\mathrm{H}^{+} \mathrm{K}^{+}$-ATPase may induce artery vasoconstriction and ischemia, resulting in PPIassociated ocular damage [5], suggesting that a possible mechanism of PPI-associated rhabdomyolysis is via $\mathrm{H}^{+} \mathrm{K}^{+}$-ATPase in other tissues. Omeprazole activates gene expression of insulin-like growth factor-binding protein-1, a key mediator for muscle protein synthesis under stress [6], via the aryl hydrocarbon receptor [7]. The aryl hydrocarbon receptor pathway may involve PPI-associated rhabdomyolysis. We need to be aware of the possibilities, though rare, of rhabdomyolysis associated with omeprazole in the ICU.

Abbreviations

CPK: Creatinine phosphokinase; PPI: Proton pump inhibitor.

\section{Competing interests}

The authors declare that they have no competing interests.

\begin{abstract}
Authors' contributions
TN contributed to study conception, acquisition and interpretation of data, and drafting of the manuscript. KT, RA, and SO contributed to acquisition and interpretation of data and drafting of the manuscript. SI and FN carried out the genetic test and contributed to interpretation of data. All authors read and approved the final manuscript.
\end{abstract}

\section{Acknowledgments}

The institutional review board at the Chiba University Graduate School of Medicine approved the genetic test in this study. Written informed consent for the publication of individual details was obtained from the participant. The consent form is in the patient's clinical notes and is available for review by the Editor-in-Chief.

\section{Author details \\ 'Department of Emergency and Critical Care Medicine, Chiba University Graduate School of Medicine, 1-8-1 Inohana, Chuo, Chiba 260-8677, Japan. ${ }^{2}$ Department of Molecular Diagnosis, Chiba University Graduate School of Medicine, 1-8-1 Inohana, Chuo, Chiba 260-8677, Japan.}

Published online: 24 July 2014
C Biomed Central

(c) 2014 Tanaka et al.; licensee BioMed Central Ltd. This is an Open Access article distributed under the terms of the Creative Commons Attribution License (http://creativecommons.org/licenses/by/4.0), which permits unrestricted use, distribution, and reproduction in any medium, provided the original work is properly credited. The Creative Commons Public Domain Dedication waiver (http://creativecommons.org/publicdomain/zero/1.0/) applies to the data made available in this article, unless otherwise stated. 


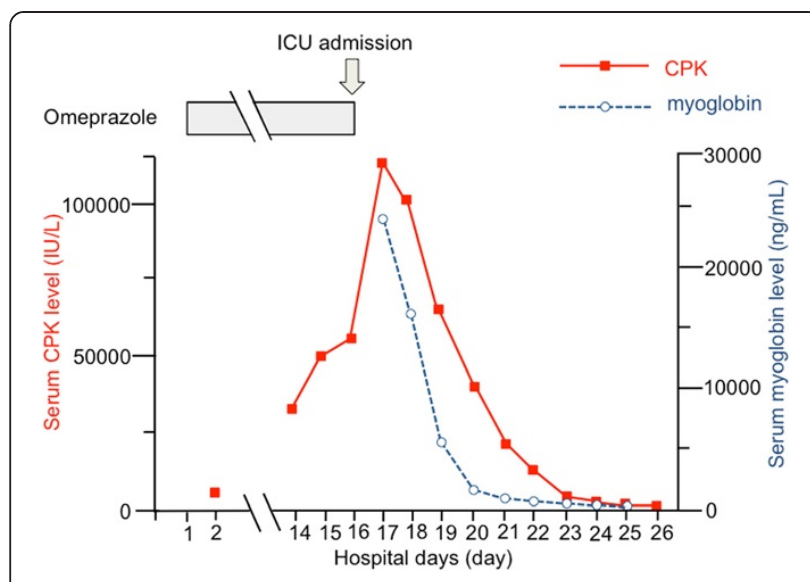

Figure 1 Course of serum creatinine phosphokinase and myoglobin levels and intravenous administration of omeprazole.

CPK, creatinine phosphokinase.

\section{References}

1. Furuta T, Shirai N, Sugimoto M, Nakamura A, Hishida A, Ishizaki T: Influence of CYP2C19 pharmacogenetic polymorphism on proton pump inhibitor-based therapies. Drug Metab Pharmacokinet 2005, 20:153-167.

2. Troger U, Reiche I, Jepsen MS, Huth C, Bode-Boger SM: Esomeprazoleinduced rhabdomyolysis in a patient with heart failure. Intensive Care Med 2010, 36:1278-1279.

3. Nozaki M, Suzuki T, Hirano M: Rhabdomyolysis associated with omeprazole. J Gastroenterol 2004, 39:86.

4. Marrelli SP, Zhao X, Allen JC: Molecular evidence for a vascular smooth muscle H + -K + -ATPase. Am J Physiol 1997, 272(2 Pt 2):H869-H874.

5. Schonhofer PS, Werner B, Troger U: Ocular damage associated with proton pump inhibitors. BMJ 1997, 314:1805.

6. Lang CH, Vary TC, Frost RA: Acute in vivo elevation of insulin-like growth factor (IGF) binding protein-1 decreases plasma free IGF-I and muscle protein synthesis. Endocrinology 2003, 144:3922-3933.

7. Murray IA, Perdew GH: Omeprazole stimulates the induction of human insulin-like growth factor binding protein-1 through aryl hydrocarbon receptor activation. J Pharmacol Exp Ther 2008, 324:1102-1110. 